
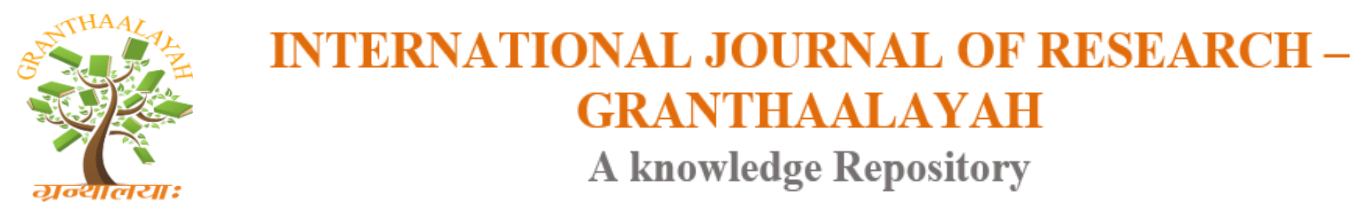

Social

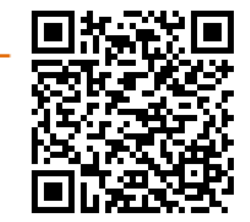

\title{
WELFARE AND SAFETY INDICATORS FOR WOMEN WASTE PICKERS IN RAJAPALYAM MUNICIPALITY
}

\author{
Dr.K.M.Ashifa ${ }^{1}$, Ms.M.Sharmila Devi ${ }^{2}$ \\ ${ }^{1}$ Asst. Professor \& Head, Department of Social Work, Kalasalingam University, India \\ ${ }^{2}$ Teaching Faculty, Department of Social Work, Kalasalingam University, India
}

\begin{abstract}
In India substantial people working in unorganized sectors as unorganized workers; transitional nature of the Indian economy, disparity in education, skill and training are some of the major factors abetting such a large concentration of workers in an area most vulnerable to exogenous economic vicissitudes. Women working in the unorganized sector deserve a separate mention as they are much marginalized (Khan, 2013). The present study is focused on women workers in unorganized sector especially the waste picking workers of Rajapalayam municipality. They are working in unprotected are in grave danger of contacting countless diseases through their daily and close contact with human waste. Some of these diseases, in addition to TB, include: campylobacter infection, cryptosporidiosis, giardiasis, and hand, and foot and mouth disease, hepatitis. According to Factories Act 1948 under section 21 to 50, the organization has to provide welfare and safety measures to protect its workers. The study tried to analyses the implementation of these welfare and safety measures among women pickers in study area. And it found that level of implementation of these measures is relatively poor. The study suggested to conduct weekly health check -up, recreation activities, counselling services, motivation trainings and awareness campaigns. Government intervention with the support of non- profit organization is to be very essential improve the quality of work life of women in unorganized sector, evidenced by the present study.
\end{abstract}

Keywords: Welfare and Safety; Women; Municipality.

Cite This Article: Dr.K.M.Ashifa, and Ms.M.Sharmila Devi. (2017). "WELFARE AND SAFETY INDICATORS FOR WOMEN WASTE PICKERS IN RAJAPALYAM MUNICIPALITY." International Journal of Research - Granthaalayah, 5(9:SE), 35-40. https://doi.org/10.5281/zenodo.1004558.

\section{Introduction}

\subsection{Waste Pickers as Human Being}

Waste pickers holds most minimal position in the hierarchy of urban informal occupations and an extensive number of those utilized in this occupation are women and children. Uneducated, 
unskilled persons, transients, those least rank in the caste hierarchy and the poorest of the poor, predominantly work as waste pickers, as they are unable to find any other kind of employment. The work of waste pickers includes collecting, separating, transporting, packaging, and sometimes processing solid waste for reuse or recycling. The relevance and the value of the work they perform is not acquiring visibility. Their economic and social contribution to the town planners, municipalities and local communities is yet to be fully acknowledged by governmental, commercial and private interests that benefit from their work (Kamala. S., Shalini, S., \&Roopa, M., 2008). Generally, there is no employer-employee relationship in this trade even though it is possible that some of the waste picking activity is organized by contractors. Waste pickers are self-employed workers with no formal legal relationship with the municipality or the recyclable traders. Waste-pickers suffer from occupation related musculo-skeletal problems, respiratory and gastro-intestinal ailments. No social security benefits are available to workers in this sector.

\section{Legislative Provisions}

In 2000, government of India passed rules for the management and handling the solid waste in municipal area and it came to effect from January 2004 under the Environment Protection Act, 1986 by the Ministry of Environment and Forests of the Government of India, after directions from the Hon. Supreme Court of India in the Almitra Patel case, mandating a comprehensive policy for collecting, handling and managing solid waste. The Rules direct the municipalities in 41 Class I municipalities to extend their mandatory responsibility (collection from common points) and undertake measures for door-step collection of waste and citizens education for source segregation (WIEGO, 2013).

Although the Rules do not make a specific mention of waste-pickers, they are explicit in offering a wide range of choices to the municipalities in the systems that they may want to adopt depending upon local conditions. Contracting out the system of doorstep garbage collection, partly or fully, to both local and multinational operators is the most popular because there is a strong lobby that believes that privatisation of garbage collection is cheaper and more efficient. Frequently these measures displace waste-pickers as the contracting party now has direct control over the waste and its disposal (Ibid).The figure (1) represents essential welfare indicators for women in unorganized sector especially for those who are working as waste pickers as well as manual scavengers.

According to the National Draft policy for ensuring decent livelihoods in the Recycling industry (2008), Waste pickers are not scavengers. They are essentially entrepreneurs whether they are waste pickers and collectors, recyclers collecting and trading recyclable commodities. Up gradation of their livelihoods is the way forward rather than an occupational shift. In many other countries, their role is formally acknowledged.

The Draft policy recognizes following basic rights of Waste Collectors as (a) Access to the waste; (b) Traditional rights over the waste collected; (c) Right of the Waste Collector to be acknowledged as 'self-employed' or 'ownaccount' worker;(d) In a bid to assist the workers in skill upgradation and to help them move up the value chain, the right to door step collection be given to erstwhile waste pickers (e) Local bodies or their agencies shall not discriminate against waste collectors on the grounds of sex, place of origin, language, religion or caste.; (f) Right to 
basic necessities like water, sanitation and facilities for clean living, rest and leisure at the place of work; and (g) Fundamental right to life and the right to good living through decent livelihood options.

STATUTORY BENIFITS
\begin{tabular}{|l|} 
Drinking water \\
Facilities for Sitting \\
First Aid Appliences \\
Latrines and Unrinals \\
Canteen Facilities \\
Spittoons \\
Lighting \\
Washing places \\
Changing rooms \\
Rest rooms \\
Maternity \& Adoption Leave \\
Medi-clai Insurence Scheme \\
Sexual Harassment Policy \\
\hline
\end{tabular}

Figure 1:

\section{Objectives of the Study}

1) To profile the welfare facilities available to the women scavengers

2) To know the elements of challenge faced by women scavengers in rajapalyam municipality

\section{Area of Study}

The study is conducted in the Rajapalayam municipality of virudhunagardistrct, Tamil Nadu Rajapalayam (is a town and a special grade municipality in Virudhunagar. It is located $85 \mathrm{~km}$ southwest of Madurai in the state of Tamil Nadu. Its main attractions are the Ayyanar Falls and the neighbour town of Srivilliputtur. The economy is based on the manufacture of textiles, and there are mills for spinning and weaving cotton, as well as a large cotton market.

\section{Virudhunagar District}

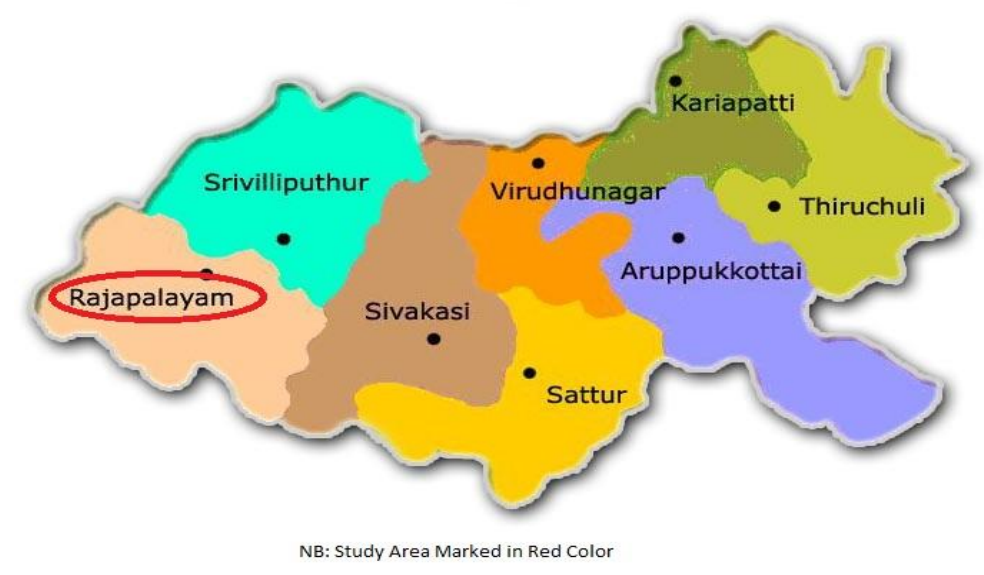




\section{Methodology}

The present study concentrated among the women waste pickers under the Rajaplayalam, Municipality. Total of 256 registered women waste pickers in Rajapalayam, among them 96 samples were selected for the study by using simple random sampling. Survey method is used for data collection by devising semi- structured interview schedule. The design of the study mainly confined with exploratory research.

\section{Result and Discussion}

Millions of people worldwide make a living collecting, sorting, recycling, and selling materials that someone else has thrown away. There is growing recognition that waste pickers contribute to the local economy, to public health and safety, and to environmental sustainability. However, they often face low social status, deplorable living and working conditions, and little support from local governments. The present study focussed on the welfare indicters and challenges faced by the waster pickers.

Table 1: Welfare Indicators For Women Waste Pickers

\begin{tabular}{|c|c|c|c|}
\hline Items & Excellent & Above average & Average \\
\hline Drinking Water & 42.6 & 32.4 & 25 \\
\hline First aid appliances & 40 & 35 & 25 \\
\hline Washing places & 30 & 15 & 55 \\
\hline Changing rooms & 40 & 35 & 25 \\
\hline Rest rooms & 30 & 25 & 45 \\
\hline $\begin{array}{l}\text { Maternity \& Adoption } \\
\text { Leave }\end{array}$ & 42 & 38 & 20 \\
\hline Sexual Harassment Policy & 20 & 17 & 63 \\
\hline $\begin{array}{l}\text { Medi-claim Insurance } \\
\text { Scheme }\end{array}$ & 66 & 20 & 14 \\
\hline
\end{tabular}

Waste picking provides crucial income for people and households. For 65 per cent of the sample, earnings from waste picking were the main source of household income. Only about one quarter had any other income. The study revealed that, they sell the reusable materials to other enterprises. The table 1 shows that the Drinking water facilities 42.6 per cent of the respondents were satisfied and the remaining 32.4 per cent of the respondents were above average of their satisfaction. First aid appliance facilities 40 per cent of the respondents were satisfied and the remaining 35 per cent of the respondents were above average of their satisfaction and the 25 per cent of the respondents were average of their first aid appliance satisfaction. 30 per cent of the respondents were satisfied with washing places facilities, but 55 per cent of the respondents were 
average of their Washing places satisfaction. The result shows that waster pickers are getting changing room as well as rest room facilities. Most of the respondent were stratifies with the maternity and adoption facilities. Awareness on sexual harassment policy in workplace is very less (63 percent) as compared to other awareness and availability of the welfare indicators. Majority of the respondents ( 66 per cent) were satisfied with the medi- clime insurance facilities of the waster pickers in Rajapalayam Municipality

Table 2: Challenges Faced by Women Waste pickers

\begin{tabular}{|l|l|l|l|l|}
\hline Items & Yes & No & Sometimes & Rare \\
\hline Conflict with co-workers & 57 & 28 & 12 & 3 \\
\hline Conflict with supervisor & 41 & 24 & 33 & 2 \\
\hline Accident & 46 & 22 & 32 & 0 \\
\hline Health issues & 83 & 17 & 0 & 0 \\
\hline Economic problems & 85 & 5 & 7 & 3 \\
\hline Mental stress & 55 & 45 & 0 & 0 \\
\hline Season effects & 32 & 25 & 13 & 30 \\
\hline
\end{tabular}

The table 2 shows that 57 per cent of the respondents have problem in conflicting with the coworkers and 41 per cent of the respondents have problem in conflicting with the supervisor. Handling waste poses many health risks. Informal waste pickers are exposed to contaminants and hazardous materials, from fecal matter and medical waste to toxic fumes and chemicals. Those who work at open dumps face risks caused by trucks, fires and surface slides. Some must take collected waste home to sort or store, introducing dangers to the home. A lack of worker protection and poor access to health care aggravate these risks. The result showed that 68 per cent of the respondents faced accident and 83 per cent of the respondents faced Health issues. And majority of the respondents (85per cent) have economic problems and they were facing mental stress due to these.

\section{Conclusion}

This paper reiterates the precariousness that characterises this labour activity and the exposure to occupational hazards within the context of informality and social insecurity. The risks mentioned by the women waste pickers reveals the need to find tactful and safe methods of supporting their work environment. The women waste pickers receiving welfare and safety indicators like, drinking water facility, canteen, medical and gloves. The given welfare activities or facilities are to be more effective and reachable among all the waste pickers equally and ethically. 


\section{References}

[1] Dias, Sonia. (2011) Integrating Informal Workers into Selective Waste Collection: The Case of Belo Horizonte, Brazil. WIEGO Policy Brief (Urban Policies) No. 4.

[2] Chikarmane, Poornima. (2012). Integrating Waste Pickers into Municipal Solid Waste Management in Pune, India. WIEGO Policy Brief (Urban Policies) No. 8.

[3] Samson, Melanie. 2009. Refusing to be Cast Aside: Waste Pickers Organising Around the World.

[4] WIEGO. 2013. Waste Pickers: The Right to Be Recognized as Workers.

[5] Dias, Sonia. 2016. "Waste Pickers and Cities." Environment and Urbanization, Vol. 28, No. 2.

[6] Achtell, Ernest. 2013. Waste Pickers and Carbon Finance: Issues to Consider. WIEGO Technical Brief No. 7. 